\title{
Decolonising Terrorism Journals
}

\author{
Ilyas Mohammed
}

check for

updates

Citation: Mohammed, I.

Decolonising Terrorism Journals.

Societies 2021, 11, 6. https://doi.org/ $10.3390 /$ soc 11010006

Received: 26 October 2020

Accepted: 12 January 2021

Published: 20 January 2021

Publisher's Note: MDPI stays neutral with regard to jurisdictional claims in published maps and institutional affiliations.

Copyright: (C) 2021 by the author. Licensee MDPI, Basel, Switzerland. This article is an open access article distributed under the terms and conditions of the Creative Commons Attribution (CC BY) license (https:/ / creativecommons.org/licenses/by/ $4.0 /)$.
Department of Sociology, Social Policy and Criminology, University of Liverpool, Liverpool L69 3BX, UK; m.ilyas@liverpool.ac.uk

\begin{abstract}
Decolonisation of knowledge over the past few years has gained much traction among scholars and students in many countries. This situation has led to calls for the decolonisation of knowledge, academia, the university, and university curricula. That said, the knowledge production side of the terrorism industry, which sits inside academia, so far has escaped calls to decolonise. This situation is somewhat surprising because the terrorism industry has had a tremendous impact on many countries, especially Muslim majority ones. The 9/11 terrorist attacks have resulted in a tremendous amount of knowledge being produced and published on terrorism and counterterrorism. However, little is known about "who is publishing on terrorism and where they are based". To this end, this paper adopts a decolonial approach and addresses the questions of "who is publishing on terrorism and where they are based" by analysing seven terrorism journals. It argues that most of the publications and knowledge on terrorism in the seven terrorism journals are produced by scholars with Western heritage and are based at Western institutions, which is connected to the coloniality of knowledge.
\end{abstract}

Keywords: decolonisation; coloniality; West; non-West; terrorism; androcentrism; journals; knowledge

\section{Introduction}

The emergence of the terrorism industry (Western countries and their agencies (intelligence agencies), non-Western countries allied to Western countries, think tanks, lobbying organisations, research centres, security firms, social science and humanities scholars, media firms, private military firms, tech companies and NGOs, all which are located in Western countries and their non-Western allies.) can be traced back to the 1970s to several Western countries, such as the US and the UK [1,2]. The industry has been dominated by scholars with Western heritage, as well as journals, think tanks, and research centres based in Western countries from the outset. However, the terrorist attacks in Western countries, from 9/11 onwards have entirely changed the industry. Western governments have invested billions of pounds, euros, and dollars into the industry, to prevent terrorism at home and abroad through mass surveillance and military invasions. The investment has resulted in the rapid growth of the knowledge production side of the industry, which has led to an increase in the number of scholars specialising on terrorism, as well as terrorism journals, research centres and websites [3-6]. The research on terrorism since $9 / 11$, as well as journal publications, books, PhDs, MA courses on terrorism and counterterrorism training programs (Used at home use and exported to non-Western countries.) have rapidly increased [7-11].

Given the close connection between the terrorism industry and governments, the knowledge on terrorism from the outset has been event and policy-driven $[6,12,13]$. This situation has led to the knowledge produced and published on terrorism by scholars to reflect the interests of Western governments [1,2,12]. The policy-driven culture that exists in the industry has also led to the silencing and omission of critical voices [12]. However, not everyone that is part of the industry is happy with how it operates. Some terrorism scholars have been highly critical of other terrorism scholars, calling them pseudoacademics and 
outright fraudsters. On the other hand, Kundani [13] and Jackson [14] have criticised the deep-seated orientalism that lies in many aspects of the industry, which silences and excludes non-Western voices.

However, most research on terrorism only focuses on methodological issues, conceptual problems, the causes of terrorism, and counterterrorism strategies [7]. In recent years scholars like Sageman [10] have argued that terrorism research has stagnated despite government investment. In contrast, others have challenged this conclusion and stated that progress had happened [15-17]. However, little research exists on "who is publishing on terrorism and where they are based". These questions are important to address because they concern the broader question on the coloniality of knowledge, which the industry has avoided. The coloniality of knowledge is the continued domination of scholars with Western heritage and Western knowledge over non-Western scholars and non-Western knowledge, which decolonial scholars have argued started with colonialism [18,19]. In the case of academia, the coloniality of knowledge has become a pressing issue in recent years in some countries, with students asking questions such as "why is my curriculum white and why isn't my professor black" and demanding that their universities address their concerns $[20,21]$.

Given the type of questions that scholars and students interested in the decoloniality of knowledge are asking, the terrorism industry and terrorism scholars and the knowledge they produce and publish can no longer escape decolonial interrogation and decolonisation. There are two main reasons why the industry cannot escape calls for decolonisation. Firstly, the scholars and the knowledge they produce and publish in journals is a product of the coloniality of knowledge. Secondly, the decoloniality of knowledge movement is fundamentally concerned with asking and addressing questions on "who produces knowledge and where the knowledge is produced". These questions also need to be asked about the knowledge production side of the terrorism industry because they lead to further questions about privileging and marginalising of scholars with non-Western heritage and Islamophobia in the industry.

The decolonisation of knowledge also means decolonising the scholar, their discipline, and institutions where they are based because all are a product of coloniality. Some scholars with Western heritage may altogether reject and actively resist calls for the decolonisation of knowledge. This opinion is not surprising because Western universities have not adequately addressed racism, orientalism, and white privilege [22,23]. Others may argue that they have been denouncing Western-centrism for a long time, which is imagined as decolonial work $[24,25]$. However, denouncing Western-centrism and refusing to benefit from and practically engaging in decolonial work are two different things. Denouncing, without rejecting the benefits of coloniality and not practically engaging in decolonial work, runs the risk of decolonisation just being a metaphor [26]. Such thinking raises several important issues for decolonial scholars and students with Western heritage. In the case of this paper, three issues are relevant. Firstly, what Tuck and Yang [26] call "moves to innocence". In academia, Western scholars and students with a Western heritage that engage in decolonial work have to remain vigilant of "moves to innocence", as described by Tuck and Yang [26]. Not being vigilant may lead them to use the "decolonial turn" as the new vogue subject for professional development and therapy to overcome guilt at the expense of decolonial work. The second issue concerns the reproduction of Western-centrism through parochialism and cronyism by excluding non-Western scholars. This situation often occurs by not referring to the work of non-Western scholars during workshops and conferences, not citing them in their work or university curricula, which Lewis [27] has called epistemic insecurity. Finally, scholars with Western heritage need to recognise that they are privileged by coloniality and may even sustain it without realising [28].

By not decolonising, it means the continuity of coloniality and marginalisation and silencing of scholars with non-Western heritage. At this intersection, this paper makes a small intervention to encourage scholars that are concerned about the coloniality of knowledge to use the decolonial approach to critically reflect on the different parts of 
the terrorism industry. This paper addresses the questions on "who is publishing on terrorism and where they are based" by analysing seven terrorism journals and identifying the scholars' heritage and gender and where their institutions are located. The paper argues that scholars with Western heritage and based at Western institutions dominate the publications in the seven journals and by extension knowledge production on terrorism. This situation indicates the coloniality of knowledge in the journals because the editors and reviewers are, for the most part, scholars, as such they are part of academia, and academia suffers from coloniality [21]. The paper first discusses why scholars and students call for the decolonisation of knowledge, which will preface the need to decolonise the knowledge production side of the terrorism industry. Secondly, the paper surveys the literature that discusses academic publications on terrorism and argues that terrorism scholars have not addressed the questions of "who is publishing on terrorism and where they are based". Thirdly, the paper details the methodological approach used to analyse the seven terrorism journals. The final part details the findings.

\subsection{Decolonisation of Knowledge}

This section of the paper will briefly discuss the decolonisation of knowledge in relation to academia, the university, the university curricula, and academic publishing. Over the last few decades, many scholars and students that have Western heritage have increasingly become aware and concerned about coloniality. However, some scholars and students with Western heritage may consider the decolonisation of knowledge as a new "vogue" field of study, but it emerged in non-Western countries several decades ago [29-31].

However, there is a recognition that coloniality is part of everyday life irrespective of whether one lives in Western or non-Western countries [18]. Coloniality refers to the continuation of colonial forms of domination and marginalisation of people with non-Western heritage in all areas of life $[18,26,32,33]$. Coloniality exists in economics, politics, culture, media, technology, academia and relevant for this paper, in the terrorism industry. In the case of academia, the coloniality of knowledge is very much a part of academic life, which also means that it is also present in the knowledge production side of the terrorism industry in the form of orientalism $[13,15,34,35]$. The reason for this is because the knowledge production side of the terrorism industry sits inside academia. It is composed of scholars who are products of the university and hold university positions and in some cases act as advisors to policymakers. Coloniality in academia is present in scholars marginalisation with non-Western heritage and exclusion from academic spaces [23]. Many scholars have discussed such experiences in recent years [23,36-41]. Such experiences, along with the existence of hierarchies in academia, continue to be shaped by coloniality, which has led scholars and students to call for the decolonisation of knowledge, especially since 2015 when South African students started a campaign called Rhodes Must Fall.

Scholars such as Alatas [42] and Alatas [43] have argued that intellectual imperialism and knowledge dependency among non-Western scholars are consequences of coloniality. Criminologists such as Agozino [44] Cunneen and Tauri [45] Liu et al. and Carrington et al. [46] have called for the decolonisation of criminology as a way to address the coloniality that plagues criminology. In doing so, they have highlighted the role that criminology played during colonialism. As a response, Agozino [47] has proposed counter criminology, Bowling [48] has suggested trans-national criminology, Carrington et al. [49] have advocated southern criminology, and Liu et al. [46] have put forward Asian criminology. Connell [50] has proposed southern theory to address coloniality in sociology, which is also the theoretical foundation of southern criminology. However, criminology's "decolonial turn" is not without criticism for reproducing coloniality [51]. Nye [52] has called for the decolonisation of religious studies and has recognised the relationship between religious studies and colonialism. Grosfoguel et al. [53], building on his earlier work on the 'structure of knowledge in Westernized universities', has called on Western universities' to decolonise. Similarly, Bhambra et al. [21] have employed decolonial approach' and called for the de- 
colonisation of the university. In recent years calls to decolonise knowledge have become entangled with the Black Lives Matter Movement, which has given the decolonisation of knowledge movement broader traction in the public and media.

Those who advocate the decolonisation of knowledge ask a range of questions and have specific demands for their universities. These questions include (a) why is the university curricula dominated by Western scholars, especially from English speaking countries, and (b) why is non-Western scholarship not afforded the same value as Western scholarship. Although both questions are essential, the more relevant for this paper is the second one. Such dominance means little or no room for non-Western scholars' work on university curricula [54]. That said, addressing such dominance will not be easy because it challenges "whiteness" in academia and raises uncomfortable questions about racism for the whole of academia, which includes academic publishing $[23,55]$. This question is important because the university curricula are composed of academic publications, and if the work of scholars with non-Western heritage is not published, then it is unlikely that it will make it on to the university curricula [56]. This situation means that terrorism studies students will not get the opportunity to engage with the ideas of terrorism scholars from countries like Malaysia and Indonesia. If the coloniality of knowledge is not addressed, it will only reinforce coloniality in all sectors in academia, ranging from the classroom, recruitment, and knowledge production to academic journals.

Some scholars may argue that non-Western scholars cannot get their work published in journals located in Western countries because they cannot produce high-quality work. However, research suggests other reasons for this, such as "gender, racial and linguistic bias" in academic publishing among editors and reviewers. Collyer [57] has identified introversion among editors of Western journals in the form of parochialism and cronyism that disadvantages scholars from non-Western countries. Braine [58] also mentions that as the major journals are in Western countries, the editors and reviewers of these journals generally tend to focus on their national audiences and may not be interested in nonWestern scholars' work. Galliers and Meadows [59] have argued that parochialism exists in North American information system journals, in that they tend to only publish articles from North American scholars. Ozbilgin [60] analysed the top 22 international human resource management journals for parochialism and reported that scholars with Western heritage dominate these journals' publications and editorial boards. Finally, by using a US school as a case study, Noonan and Bristol [61] have argued that parochialism also exists in the recruitment of academic staff.

Other research has identified gender and racial bias in academic publishing, despite the double-blind peer-review process. In the case of gender bias, Lundine et al. [62] have argued that gender bias exists within academic publishing, even though editors claim to be "gender blind or gender-neutral". In doing so, they fail to recognise the broader structures that produce gender inequalities within academia and society in general [63]. There is also research that suggests the presence of racial bias in academic publishing. Anderson [64] has argued that prestigious journals, which are often located in Western countries and have white editorial boards, rarely publish black scholars' work, especially if it challenges the "white" view of race issues. Dowson et al. [65] have also highlighted racism in academic publishing and have argued for an "antiracist framework for scholarly publishing". Like gender, the presence of racial bias is a reflection of racism in academia and broader society. Another type of bias that the scholars have highlighted is "linguistic bias", which is experienced by scholars who publish in their second or even third language, which in many cases is English because of the dominance of English language journals. Scholars who have non-Western heritage and based in non-Western countries want to publish in Western journals, especially English language journals, for four reasons. Firstly, Western journals are considered prestigious, meaning that scholars will gain recognition and promotion by publishing in them. Secondly, the global university ranking system depends on publishing in prestigious journals located in Western countries. Thirdly, there is the assumption that publishing in Western journals will lead to more citations, which 
means more recognition and finally, big publishing houses are located in Western countries, mostly English-speaking ones [57,66].

Academic publications' bias is also connected to the university library's coloniality because what is on the bookshelves and digital databases reflects what is published and purchased. If non-Western scholars' work is not published in academic journals, it is not likely to appear on university library shelves or databases, which means that it will not reach university curricula. The call to decolonise the university by extension also means decolonising the university library because they are repositories of knowledge that scholars use to produce articles and books and students use to write their essays and dissertations. By not decolonising the library would mean maintaining the coloniality of knowledge [67].

\subsection{Survey of Terrorism Publications}

This section of the paper will briefly survey terrorism research that has discussed terrorism publications to identify whether scholars have discussed the question of "who is publishing on terrorism and where they are based".

Schmid and Jongman [6] in their book titled "Political Terrorism: A New Guide to Actors, Authors, Concepts, Data Bases, Theories, and Literature" provide a list of the most cited terrorism scholars, as well as a reading list for newcomers to the industry. However, there is no discussion about the heritage or gender of the scholars they mention or where they are based. The list of most cited scholars consists of 34 scholars. A quick google search revealed that all of them have Western heritage and are mostly male and based in Western institutions. The reading list contains 155 publications, and a quick google search revealed that the list is dominated by scholars with Western heritage and are mostly male and based in Western institutions. In a book titled "Research in Terrorism, Trends, Achievements $\mathcal{E}$ Failures", published in 2004, Gordon [7] discusses the growth of knowledge in the terrorism industry and looks at the relationship between publications and terrorist attacks, but there is no mention the heritage or gender or where the scholars are based. In another book edited by Chen et al. [68] and titled "Terrorism Informatics: Knowledge Management and Data Mining for Homeland Security", Sam Raphael identifies 31 leading terrorism scholars but does not mention their heritage or gender and where they are based. In recent years, Silke and Schmidt-Petersen [69] identified the top 100 most cited terrorism articles, but like the previous publications, there is no mention of the scholars' heritage or gender or where they are based. Schuurman [70] reviewed the data on methods and authorship of terrorism articles published between 2007 and 2016 and argued that most articles are single-authored, but there is no mention about the scholars' heritage and gender or where they are based. Scrivens [71] conducted a study on terrorism and counterterrorism related to MAs and PhDs completed between 2013 and 2017, but he does not mention gender or heritage or where the students are based.

From this short survey, it is clear that the scholars do not discuss who is publishing on terrorism and where they are based. Some scholars may ask why it is essential to identify the scholars' heritage and gender and where they are based, which is a legitimate question, given that the terrorism industry presents itself as being concerned with fighting terrorism. This question's response is straightforward because it is connected to the coloniality of knowledge and the privileging of scholars with Western heritage and based in institutions in Western countries and the marginalisation of non-Western scholars within the terrorism industry. However, not asking and addressing "who is publishing on terrorism and where they are based" questions will only reinforce the coloniality of knowledge and justify the coloniality of being.

\section{Materials and Methods}

This part of the paper will discuss the methodological approach taken to research for this paper. The paper analysed seven terrorism journals (Critical Studies on Terrorism; Behavioral Sciences of Terrorism and Political Aggression; Studies in Conflict and Terrorism; Terrorism and Political Violence; Security Studies; Media, War and Conflict; Journal 
of Policing, Intelligence and Counter-Terrorism). The criteria for choosing the journals mentioned above are their popularity and publishing articles in the English language. To answer the questions on "who is publishing on terrorism and where they are based", each edition of the seven journals between 2015 and 2019 was analysed. In doing so, the scholars' heritage, gender, where they are based, and how many articles they published in the journal are identified.

Although the articles provided the scholars' names and the institution where they are based, this information was insufficient to determine their heritage, gender, or up-to-date information on where they were based. Therefore, a quick Google search was conducted to find the institutional profiles of scholars. The profile pages provided information about the scholars' heritage and gender and where their institution was based. A simple "three category heritage criteria" was developed to place the scholars (Western, Centre NonWestern and non-Western). For example, Western heritage refers to where the scholars were born and where their families came from (Europe, Australasia, North America). While Centre Non-Western refers to scholars who were born in or have families who come from countries that are not geographically located in the West but are as wealthy and developed as their Western counterparts, such as Singapore. Finally, non-Western heritage refers to scholars born in or who have families who come from countries that are neither wealthy nor developed as their centre non-Western counterparts, but they geographically share the same region as the previous category, such as Indonesia. After analysing the journals, the data was added to seven separate Excel tables.

\section{Limitations}

There are two significant limitations to the analysis. The first limitation is that only seven journals were analysed and including more journals would have led to making some important inferences. The second limitation is that only journals which publish in the English language were analysed. It would have been better to include other journals published in other languages such as Arabic, Malaya, and Bahasa.

\section{Results}

\subsection{Research Findings}

In this section of the paper, the findings from all seven journals are presented. The first part presents the findings from each journal and shows who is publishing in the journal with respect to heritage, gender, and institution. The second part combines the findings from each journal and summarises the findings in terms of publications by heritage, gender, and institution.

\subsection{Critical Studies on Terrorism}

The first journal that was analysed is called Critical Studies on Terrorism (see Appendix A). The journal had 194 articles published in it between 2015 and 2019. From the 194 articles, 104 or $54 \%$ of the articles are authored by male scholars and 90 or $46 \%$ by female scholars. In total, 157 or $81 \%$ of the 194 articles published in the journal are authored by scholars with Western heritage. From the 194 articles, 81 or $42 \%$ of the articles published are authored by male scholars and 76 or $39 \%$ by female scholars with Western heritage. All of them are based at institutions in Western countries. In contrast, scholars with non-Western heritage account for only 32 or $16 \%$ of the articles published from a total of 194 articles published. With 22 or $11 \%$ of the articles authored by male scholars and 10 or $5 \%$ by female scholars. From the 32 or $16 \%$ articles published 30 or $15 \%$ of the articles are authored by scholars based at institutions in Western countries, which means that 20 or $10 \%$ of the articles published are authored by male scholars and 10 or $5 \%$ by female scholars. Scholars with non-Western heritage and based at non-Western institutions account for only 2 or $1 \%$ of the articles published, with all of the scholars being male. However, scholars with centre non-Western heritage authored only 5 or 3\% out of 194 articles published. With 
1 or $1 \%$ of the articles being authored by male scholars and 4 or $2 \%$ by female scholars. All of the scholars are based at institutions in centre non-Western countries.

The disparity between the articles authored by scholars with Western and non-Western heritage, including scholars with centre non-Western heritage is evident in the journal. From a total of 194 articles published, 157 or $81 \%$ of the articles are authored by scholars with Western heritage. Scholars with non-Western heritage, including those with centre non-Western heritage, only account for 37 or $19 \%$ of the articles published. Scholars with Western heritage have authored 120 or $62 \%$ more articles than scholars that do not have a Western heritage. Female scholars with Western heritage account for 76 or $39 \%$ of the 194 articles published. In contrast, female scholars with non-Western and centre nonWestern heritage account for only 12 or $6 \%$ out of the 194 articles published. Female scholars with Western heritage have authored 64 or 33\% more articles than their non-Western and centre non-Western counterparts. From a total of 194 articles published, 189 or 97\% of the articles are authored by scholars that are based at institutions in Western countries (scholars with Western heritage and non-Western heritage). In contrast, scholars based at institutions in non-Western and centre non-Western countries have only authored 7 or $3 \%$ of the total articles published. Scholars who work at institutions in Western countries have authored 189 or $97 \%$ more articles than their counterparts based at institutions in non-Western and centre non-Western countries.

\subsection{Journal of Policing, Intelligence, and Counterterrorism}

The second journal analysed is the Journal of Policing, Intelligence and CounterTerrorism (see Appendix A). Between 2015 and 2019, the journal published 143 articles. From the 143 articles published, 109 or $76 \%$ of the articles are authored by male scholars and 34 or $24 \%$ by female scholars. In total, 119 or $83 \%$ of the 143 articles published are authored by scholars with Western heritage. From the 143 articles published, 90 or $63 \%$ of the articles are authored by male scholars and 29 or $22 \%$ by female scholars with Western heritage. All the scholars are based at institutions in Western countries. In contrast, scholars who have non-Western heritage only authored 19 or $13 \%$ of the total 143 articles published, with 15 or $10 \%$ of articles being authored by male scholars and 4 or $3 \%$ by female scholars. From the 19 or $13 \%$ of the articles published, 10 or $7 \%$ of the articles are authored by male scholars and 3 or $2 \%$ by female scholars that are based at institutions in Western countries. In total, 13 or $9 \%$ of the articles published are authored by scholars with nonWestern heritage but are based at institutions in Western countries. From the 19 or $13 \%$ of the articles published, 5 or $3 \%$ of the articles are published and authored by male scholars and 1 or $1 \%$ by female scholars with non-Western heritage and all are based at institutions in non-Western countries. In total, 6 or $4 \%$ of the articles published are authored by scholars that are based at institutions in non-Western countries. From the 143 articles, only 5 or $4 \%$ are authored by scholars with centre non-Western heritage, with 5 or $3 \%$ being authored by male scholars and 1 or $1 \%$ by female scholars. This situation means that 5 or $4 \%$ of the articles published are authored by scholars based at institutions in centre non-Western countries.

The disparity between the articles authored by scholars with Western and non-Western heritage, including scholars with a centre non-Western heritage in this journal is apparent. From a total of 143 articles published, 119 or $83 \%$ of the articles are authored by scholars with Western heritage. Scholars who have non-Western and centre non-Western heritage only account for 24 or $16 \%$ of the articles published. Scholars with Western heritage have authored 95 or $66 \%$ more articles than scholars that do not have a Western heritage. Female scholars with Western heritage account for 29 or $20 \%$ of the 143 articles published. In contrast, female scholars with non-Western and centre-non-Western heritage account for only 5 or $3 \%$ of the 143 articles published. However, female scholars with Western heritage authored 24 or $17 \%$ more articles than their non-Western and centre non-Western counterparts. From the total of 143 articles published 132 or $92 \%$ of the articles are authored by scholars based at institutions in Western countries (scholars with Western and non- 
Western heritage). In contrast, scholars based at institutions in non-Western countries, including centre non-Western countries account for only 11 or $8 \%$ of the articles published.

\subsection{Behavioural Sciences of Terrorism and Political Aggression}

The third journal that was analysed is called "Behavioural Sciences of Terrorism and Political Aggression" (see Appendix A). This journal published 140 articles between 2015 and 2019 , with 93 or $66 \%$ of the articles being authored by male scholars and 48 or $34 \%$ by female scholars. In total, 120 or $86 \%$ of the articles published are authored by scholars with Western heritage. From the 140 articles published, 78 or $56 \%$ of the articles are authored by male scholars and 42 or $30 \%$ by female scholars with Western heritage. All the scholars are based at institutions in Western countries. In contrast, scholars with non-Western heritage account for only 19 or $13 \%$ of the total 140 articles published, with 14 or $10 \%$ of the articles being authored by male scholars and 5 or $4 \%$ by female scholars. Among the 19 articles, 13 or $9 \%$ of the articles are authored by scholars based at institutions in Western countries, with 11 or $8 \%$ of the articles being authored by male scholars and 2 or $1 \%$ by female scholars. Scholars with non-Western heritage and based at institutions in non-Western countries authored 6 or $4 \%$ of the articles published, with 3 or $2 \%$ of the articles being authored by male scholars and 3 or $2 \%$ by female scholars. Scholars with centre non-Western heritage have only authored 1 or $1 \%$ of the articles, and all are based at institutions in a centre non-Western country.

The disparity between the articles authored by scholars with Western and non-Western heritage, including scholars with a centre non-Western heritage in this journal is apparent. From a total of 140 articles published, 120 or $86 \%$ of the articles are authored by scholars with Western heritage. While articles authored by scholars with non-Western and centre non-Western heritage only amount to 20 or $14 \%$ of the articles published. Scholars with Western heritage have authored 66 or $72 \%$ more articles than scholars that do not have a Western heritage. Female scholars with Western heritage account for 42 or $30 \%$ of the 140 articles published. In contrast, female scholars with non-Western and centre-nonWestern heritage account for 3 or $2 \%$ of the 143 articles published. Female scholars with Western heritage have authored 39 or $28 \%$ more articles than their non-Western and centre non-Western counterparts. From a total of 140 articles published, 133 or $95 \%$ of the articles are authored by scholars (scholars with Western and non-Western heritage) based at institutions in Western countries. In contrast, scholars based at institutions in non-Western countries authored 7 or $5 \%$ of the articles published. Scholars based at institutions in Western countries have authored 133 or $90 \%$ more articles than their counterparts based at institutions in non-Western and centre non-Western countries.

\subsection{Terrorism and Political Violence}

The fourth journal that was analysed is called "Terrorism and Political Violence" (see Appendix A). This journal published 387 articles between 2015 and 2019. From the 387 articles, 294 or $76 \%$ of the articles are authored by male scholars and 96 or $24 \%$ by female scholars. In total, 326 or $84 \%$ of the articles are authored by scholars with Western heritage, with 238 or $61 \%$ of the articles being authored by male scholars and 88 or $23 \%$ by female scholars with Western heritage. From the 326 or $84 \%$ of the articles published, 320 or $83 \%$ of the articles are authored by scholars based at institutions in Western countries, with 234 or $60 \%$ being authored by male scholars and 86 or $22 \%$ by female scholars. In contrast, 5 or $1 \%$ of the articles are authored by scholars with Western heritage but are based at institutions in non-Western countries, with 3 or $1 \%$ of the articles being authored by male scholars and 2 or $1 \%$ by female scholars. The scholars with non-Western heritage account for 39 or $10 \%$ of the total articles published, with 36 or $9 \%$ of the articles being authored by male scholars and 3 or $1 \%$ by female scholars. From the 39 or $10 \%$ of the articles published, 20 or $5 \%$ of the articles are authored by scholars based at institutions in Western countries, with 17 or $4 \%$ of the articles being authored by male scholars and 3 or $1 \%$ by female scholars. Scholars with non-Western heritage and based at institutions in non-Western countries account for 
only 19 or $5 \%$ of the articles published, with all of the scholars being male. Scholars with centre non-Western heritage authored 22 or $6 \%$ from the 387 articles published, with 20 or $5 \%$ being authored by male scholars and 2 or $1 \%$ by female scholars. All of the scholars are based at institutions in centre non-Western countries.

The disparity between the articles authored by scholars with Western and non-Western heritage, including scholars with a centre non-Western heritage in this journal is apparent. From a total of 387 articles published, 326 or $84 \%$ of the articles are authored by scholars with Western heritage. While articles authored by scholars with non-Western and centre non-Western heritage only amount to 61 or $16 \%$ of the articles published. Scholars with Western heritage have authored 265 or $68 \%$ more articles than scholars that do not have a Western heritage. Female scholars with Western heritage account for 88 or $23 \%$ of the 387 articles published. In contrast, female scholars with non-Western and centre-nonWestern heritage account for 3 or $1 \%$ of the 387 articles published. Female scholars with Western heritage have authored 83 or $22 \%$ more articles than their non-Western and centre non-Western counterparts. From a total of 387 articles published, 340 or $88 \%$ of the articles are authored by scholars based at Western countries' institutions (scholars with Western heritage and non-Western heritage). In contrast, scholars based at institutions in nonWestern countries have authored 47 or $12 \%$ of the articles published. Scholars based at institutions in Western countries have authored 293 or 76\% more articles than their counterparts based at institutions in non-Western and centre non-Western countries.

\subsection{Security Studies}

The fifth journal that was analysed is called "Security studies" (see Appendix A). The journal published 188 articles between 2015 and 2019. From the 188 articles published, 139 or $74 \%$ of the articles are authored by male scholars and 49 or $26 \%$ by female scholars. In total 162 or $86 \%$ of the articles are authored by scholars with Western heritage, with 118 or $63 \%$ of the articles being authored by male scholars and 44 or $23 \%$ by female scholars. All of the scholars are based at institutions in Western countries. Scholars with non-Western heritage account for only 20 or $11 \%$ from the total of 188 articles published, with 15 or $8 \%$ of the articles being authored by male scholars and 5 or $3 \%$ by female scholars. Among these scholars, 15 or $8 \%$ of the articles are authored by scholars based at institutions in Western countries, with 10 or $5 \%$ of the articles authored by male scholars and 5 or $3 \%$ by female scholars. Scholars with non-Western heritage and based at institutions in non-Western countries only account for 5 or $3 \%$ of the articles published, with all of the scholars being male. Out of the 188 articles published, 6 or $3 \%$ of the articles are authored by scholars with centre non-Western heritage, and all are male and based at institutions in centre non-Western countries.

The disparity between the articles authored by scholars with Western and non-Western heritage, including scholars with a centre non-Western heritage in this journal is evident. From a total of 188 articles published, 162 or $86 \%$ of that articles are authored by scholars with Western heritage. While articles authored by scholars with non-Western heritage, including those with centre non-Western heritage only amount to 26 or $14 \%$ of the articles published. Female scholars with Western heritage account for 44 or $23 \%$ of the 188 articles published. In contrast, female scholars with non-Western and centre-non-Western heritage account for 3 or $1 \%$ of the 188 articles published. Female scholars with Western heritage have authored 41 or $22 \%$ more articles than their non-Western and centre non-Western counterparts. Scholars with Western heritage have authored 136 or $60 \%$ more articles than scholars that do not have a Western heritage. From 188 articles published, 177 or $94 \%$ of the articles are authored by scholars based at institutions in Western countries (scholars with Western heritage and non-Western heritage). While scholars that are based at institutions in non-Western and centre non-Western countries have authored 11 or $6 \%$ of the articles published. Scholars based at institutions in Western countries have authored 166 or $88 \%$ more articles than their counterparts based at institutions in non-Western countries. 


\subsection{Studies in Conflict and Terrorism}

The sixth journal that was analysed is called "Studies in Conflict \& Terrorism" (see Appendix A). This journal published 423 articles between 2015 and 2019, with 280 or $66 \%$ of the articles being authored by male scholars and 143 or $34 \%$ by female scholars. In total 347 or $82 \%$ of the articles are authored by scholars with Western heritage, with 256 or $53 \%$ of the articles being authored by male scholars and 121 or $27 \%$ by female scholars. From these scholars, 345 or $82 \%$ of the articles are authored by scholars based at institutions in Western countries, with 225 or $53 \%$ of the articles being authored by male scholars and 120 or $27 \%$ by female scholars. Only 2 or $1 \%$ of the articles are authored by scholars with Western heritage and are based at institutions in non-Western countries, with 1 or $1 \%$ (one article each) being authored by male and female scholars. However, scholars with non-Western heritage account for 40 or $9 \%$ of the 423 articles published, with 33 or $8 \%$ of the articles being authored by male scholars and 7 or $2 \%$ by female scholars. From these scholars, 24 or $6 \%$ of the articles are authored by scholars based at institutions in Western countries, with 17 or $4 \%$ of the articles authored by male scholars and 7 or $2 \%$ by female scholars. Scholars with non-Western heritage and based at institutions in nonWestern countries account for 16 or $4 \%$ of the articles published, with all of them being male scholars. Whereas articles published by scholars with centre non-Western heritage amount to 36 or $9 \%$ from 423 articles published, with 21 or $5 \%$ of the articles being authored by male scholars and 15 or $4 \%$ by female scholars. All of the scholars are based at institutions in centre non-Western countries.

The disparity between the articles authored by scholars with Western and non-Western heritage, including scholars with a centre non-Western heritage in this journal is apparent. From the 423 articles, 347 or $82 \%$ of the articles are authored by scholars with Western heritage. While articles authored by scholars with non-Western heritage, including those with centre non-Western heritage only amount to 76 or $18 \%$ of the articles published. Scholars with Western heritage have authored 271 or $64 \%$ more articles than scholars that do not have a Western heritage. Female scholars with Western heritage account for 121 or $27 \%$ of the 423 articles published. In contrast, female scholars with non-Western and centre non-Western heritage account for 22 or $5 \%$ of the 423 articles published. Female scholars with Western heritage have authored 99 or $22 \%$ more articles than their nonWestern and centre non-Western counterparts. From a total of 423 articles published, 385 or $91 \%$ of the articles are authored by scholars based at Western countries' institutions (Western heritage and non-Western heritage). In contrast, scholars based at institutions in non-Western and centre non-Western countries have authored 62 or $14 \%$ of the articles published. Scholars based at institutions in Western countries have authored 323 or $77 \%$ more articles than their counterparts based at institutions in non-Western and centre non-Western countries.

\subsection{Media, War, and Conflicts}

The last journal that was analysed is called "Media, War \& Conflicts" (see Appendix A). The journal published 228 articles between 2015 and 2019, with 137 or $60 \%$ of the articles being authored by male scholars and 91 or $40 \%$ by female scholars. In total, 186 or $81 \%$ of the articles are authored by scholars with Western heritage. From these articles, 110 or $48 \%$ are authored by male scholars and 76 or $33 \%$ by female scholars. All of the scholars are based at institutions in Western countries. Scholars with non-Western heritage account for 12 or $5 \%$ of the articles, with 8 or $3 \%$ of the articles being authored by male scholars and 4 or $2 \%$ by female scholars. From these articles, 7 or $3 \%$ of the articles are authored by scholars based at institutions in Western countries, with 3 or $1 \%$ of the articles authored by male scholars and 4 or $2 \%$ by female scholars. Scholars with non-Western heritage and based at institutions in non-Western countries account for 5 or $2 \%$ of the articles published, and female scholars published zero articles. Scholars with centre non-Western heritage account for 30 or $13 \%$ of the articles published, with 19 or $8 \%$ of the articles being authored 
by male scholars and 11 or $5 \%$ by female scholars. All the scholars are based at institutions in centre non-Western countries.

The disparity between the articles authored by scholars with Western and non-Western heritage, including scholars with centre non-Western heritage in this journal is apparent. From the 228 articles published, 186 or $82 \%$ of the articles are authored by scholars with Western heritage. At the same time, articles authored by scholars with non-Western heritage, including those with centre non-Western heritage only amount 32 or $18 \%$ of the articles. Scholars with Western heritage have authored 154 or $64 \%$ more articles than scholars that do not have a Western heritage. Female scholars with Western heritage account for 76 or $33 \%$ of the 228 articles published. In contrast, female scholars with non-Western and centre-non-Western heritage account for 15 or $6 \%$ of the 228 articles published. Female scholars with Western heritage have authored 61 or $27 \%$ more articles than their nonWestern and centre non-Western counterparts. From a total of 228 articles published, 193 or $85 \%$ of the articles are authored by scholars based at institutions in Western countries (scholars with Western heritage and non-Western heritage). While scholars that are based at institutions in non-Western and centre non-Western countries have authored 35 or $15 \%$ of the articles published. Scholars based at institutions in Western countries have authored 158 or $70 \%$ more articles than their counterparts based at institutions in non-Western and centre non-Western countries.

\section{Discussion}

\subsection{Distribution across the Seven Journals by Heritage}

From the seven journals, 1704 articles were published between 2015 and 2019, with 1417 or $83 \%$ of the articles being authored by scholars with Western heritage. In comparison articles authored by scholars with non-Western and centre non-Western heritage only amount to 287 or $17 \%$ of the articles published. These results show that scholars with Western heritage have authored 1130 or $65 \%$ more articles than their counterparts with non-Western and centre non-Western heritage. This situation means that scholars with Western heritage dominate the publishing and by extension knowledge production on terrorism in the seven journals. This also means the scholars with Western heritage have the power to dictate the theoretical and methodological direction of terrorism knowledge and if they are government advisers or media pundits, they able to influence policy and the public, which could be detrimental for people with non-Western heritage and non-Western countries.

\subsection{Distribution across the Seven Journals by Gender}

From the seven journals analysed, 1704 articles were published between 2015 and 2019 , with 1157 or $68 \%$ of the articles authored by male scholars and 547 or $32 \%$ by female scholars. Moreover, male scholars have authored 1157 or $68 \%$ more articles than their female counterparts. Therefore, male scholars dominate the publishing and by extension, knowledge production on terrorism in the seven journals, which suggests androcentrism.

\subsection{Distribution across Seven Journals by the Institution}

Articles authored by scholars based at institutions in Western countries (scholars Western heritage and non-Western heritage) amount to 1590 or $90 \%$ of the 1704 articles published. In contrast, articles authored by scholars based at institutions in non-Western and centre non-Western countries amount to 175 or $10 \%$ of the 1704 articles published. This situation means that scholars based at institutions in Western countries have authored 1415 or $80 \%$ more articles than their counterparts based at institutions in non-Western and centre non-Western countries. It also means that institutions based in Western countries dominate the publishing and by extension, knowledge production on terrorism in the seven journals. This situation affords Western institutions a lot of power to dictate the theoretical and methodological direction of terrorism knowledge and could be detrimental for people with non-Western heritage and non-Western countries. 


\section{Conclusions}

Terrorism has caused more death and destruction in non-Western countries, especially Muslim majority countries, than Western countries. With this being the case, one would expect that the authorship of journal articles and by extension, knowledge production on terrorism would reflect the impact of terrorism. However, the analysis of the seven journals revealed a different picture. The analysis revealed that publications and knowledge production on terrorism are dominated by scholars with Western heritage and institutions based in Western countries. In fact, scholars with Western heritage have published 1417 or $83 \%$ more articles than their non-Western and centre non-Western counterparts. The institutional analysis showed that scholars (scholars with Western and non-Western heritage) based at institutions in Western countries had published 1590 or $90 \%$ more articles than their counterparts based at institutions in non-Western and centre non-Western counterparts. Statistically, these findings demonstrate that the West dominates knowledge production on terrorism, but sociopolitically, they signify many other issues.

These findings signify that scholars with Western heritage control the discourse on terrorism, including deciding on "who is and who is not a terrorist" and "what actions constitute as terrorism and what actions do not". Such control affords scholars with Western heritage and Western institutions a lot power to determine the direction of terrorism research and terrorism research methodologies. They also have the power to influence the policies of governments and international institutions, the media, the public imaginations on terrorism, and interethnic and inter-religious relations [25]. Such power can encourage Islamophobia among policymakers and the public in Muslim majority and minority countries, as we have seen in countries like the US, UK, and France.

The dominance of scholars with Western heritage and institutions based in Western countries in the seven journals could be due to the presence of coloniality because of the colonial legacy of knowledge production and the university, as argued by decolonial scholars [72,73]. Academic publishing is part of academia for two main reasons. Firstly, scholars publish their research and review the submissions of other scholars, and finally, publishing is an essential factor in university rankings. Therefore, if academia suffers from coloniality, then the editors and reviewers of the seven terrorism journals, and for this matter, other journals could also have been impacted by coloniality because they are a product of academia.

The literature on publishing also gives us some insight into the reasons behind the domination mentioned above, which is connected to the coloniality of knowledge [72,73]. The first reason for the gap could be that the editors and reviewers think that scholars with non-Western heritage cannot produce high-quality work. A second reason could be that journal editors and reviewers reject articles written by scholars with "unfamiliar names", such as non-Western names. A third reason could be because the work or nonWestern challenges the dominant view on terrorism or the views held by editors and reviewers. A fourth reason could be the belief among journal editors and reviewers that non-Western scholars have nothing of interest to say on terrorism and their contribution will not add any value to terrorism knowledge. A fifth reason could be because of the culture of cronyism among the journal editors and reviewers, which means the exclusion of non-Western scholars because they are not part of the "inner group". A final reason could be that journal editors and reviewers are not interested in what non-Western scholars have to say on terrorism, which may be based on the assumption that nothing good comes from non-Western countries. However, a more accurate picture of why scholars with Western heritage and Western institutions dominate publishing and knowledge production on terrorism can only be identified if the scholars, journal editors, and reviewers were interviewed, as [57] Collyer (2018) did in her article titled "Global patterns in the publishing of academic knowledge: Global North, Global South". 
Although this paper analysed only seven journals, one thing is clear. If scholars with non-Western and centre non-Western heritage are not published in the seven journals or other journals, it will not make it on the bookshelves and digital databases of university libraries. As such, the work of non-Western scholars will not be cited by scholars with Western heritage. It will not make it on to the curricula of university terrorism studies programmes or counterterrorism training programmes. This situation is a concern because it reflects scholars and students' concerns who are advocating the decolonisation of knowledge, academia, the university, and university curricula. A solution to the Western domination in publishing on terrorism could be for non-Western countries to develop transregional publishing circuit, which circumvents Western journals and publishing houses.

However, scholars interested in the decoloniality of knowledge must take up the challenge of investigating why scholars with Western heritage and Western institutions dominate the knowledge production side of the terrorism industry because the consequences of the domination are far-reaching and go beyond academia for non-Western countries.

Funding: This research received no external funding.

Institutional Review Board Statement: This research did not need any type of approval from any board.

Informed Consent Statement: No informed consent was needed for this research.

Data Availability Statement: The research data for this article is located in Appendix A.

Conflicts of Interest: The author declares no conflict of interest.

Appendix A

Table A1. Journal analysis—critical studies on terrorism.

\begin{tabular}{|c|c|c|c|}
\hline & Male & Female & Total Publications \\
\hline Western heritage & $81=42 \%$ & $76=39 \%$ & $157=81 \%$ \\
\hline Based at Western University & $81=42 \%$ & $76=39 \%$ & $157=81 \%$ \\
\hline Based at non-Western University & $0=0 \%$ & $0=0 \%$ & $0=0 \%$ \\
\hline Non-West heritage & $22=11 \%$ & $10=5 \%$ & $32=16 \%$ \\
\hline Based at Western University & $20=10 \%$ & $10=5 \%$ & $30=15 \%$ \\
\hline Working in non-Western University & $2=1 \%$ & $0=0 \%$ & $2=1 \%$ \\
\hline Centre Non-West heritage & $1=1 \%$ & $4=2 \%$ & $5=3 \%$ \\
\hline Based at Centre Non-West heritage & $1=1 \%$ & $4=2 \%$ & $5=3 \%$ \\
\hline Total & $104=54 \%$ & $90=46 \%$ & 194 \\
\hline \multicolumn{3}{|c|}{ Western heritage } & $157=81 \%$ \\
\hline \multicolumn{3}{|c|}{$\begin{array}{c}\text { Non-Western and } \\
\text { Centre non-Western heritage }\end{array}$} & $37=19 \%$ \\
\hline
\end{tabular}


Table A2. Journal of policing, intelligence, and counterterrorism.

\begin{tabular}{|c|c|c|c|}
\hline & Male & Female & Total Publications \\
\hline Western heritage & $90=63 \%$ & $29=20 \%$ & $119=83 \%$ \\
\hline Based at Western University & $90=63 \%$ & $29=22 \%$ & $119=82 \%$ \\
\hline Based at non-Western University & $0=0 \%$ & $0=0 \%$ & $0=0 \%$ \\
\hline Non-Western heritage & $15=10 \%$ & $4=3 \%$ & $19=13 \%$ \\
\hline Based at Western University & $10=7 \%$ & $3=2 \%$ & $13=9 \%$ \\
\hline Based at non-Western University & $5=3 \%$ & $1=0.7 \%$ & $6=4 \%$ \\
\hline Centre Non-West heritage & $4=3 \%$ & $1=1 \%$ & $5=4 \%$ \\
\hline Based at Centre Non-West heritage & $4=3 \%$ & $1=1 \%$ & $5=4 \%$ \\
\hline Total & $109=76 \%$ & $34=24 \%$ & 143 \\
\hline \multicolumn{3}{|c|}{ Western heritage } & $119=83 \%$ \\
\hline \multicolumn{3}{|c|}{$\begin{array}{c}\text { Non-Western and } \\
\text { Centre non-Western heritage }\end{array}$} & $24=17 \%$ \\
\hline
\end{tabular}

Table A3. Behavioural sciences of terrorism and political aggression.

\begin{tabular}{|c|c|c|c|}
\hline & Male & Female & Total Publications \\
\hline Western heritage & $78=56 \%$ & $42=30 \%$ & $120=86 \%$ \\
\hline Based at Western University & $78=56 \%$ & $42=30 \%$ & $120=86 \%$ \\
\hline Based at non-Western University & $0=0 \%$ & $0=0 \%$ & $0=0 \%$ \\
\hline Non-Western heritage & $14=10 \%$ & $5=4 \%$ & $19=13 \%$ \\
\hline Based at Western University & $11=8 \%$ & $2=1 \%$ & $13=9 \%$ \\
\hline Based at non-Western University & $3=2 \%$ & $3=2 \%$ & $6=4 \%$ \\
\hline Centre Non-West heritage & $1=1 \%$ & $0=0 \%$ & $1=1 \%$ \\
\hline Based at Centre Non-West heritage & $1=1 \%$ & $0=0 \%$ & $1=1 \%$ \\
\hline Total & $93=66 \%$ & $48=34 \%$ & 140 \\
\hline \multicolumn{3}{|c|}{ Western heritage } & $120=86 \%$ \\
\hline \multicolumn{3}{|c|}{$\begin{array}{l}\text { Non-Western and } \\
\text { Centre non-Western heritage }\end{array}$} & $20=14 \%$ \\
\hline
\end{tabular}


Table A4. Terrorism and political violence.

\begin{tabular}{|c|c|c|c|}
\hline & Male & Female & Total Publications \\
\hline Western heritage & $238=61 \%$ & $88=23 \%$ & $326=84 \%$ \\
\hline Based at Western University & $234=60 \%$ & $86=22 \%$ & $320=83 \%$ \\
\hline Based at non-Western University & $3=1 \%$ & $2=1 \%$ & $6=2 \%$ \\
\hline Non-Western heritage & $36=9 \%$ & $3=1 \%$ & $39=10 \%$ \\
\hline Based at Western University & $17=4 \%$ & $3=1 \%$ & $20=5 \%$ \\
\hline Based at non-Western University & $19=5 \%$ & $0=0 \%$ & $19=5 \%$ \\
\hline Centre Non-West heritage & $20=5 \%$ & $2=1 \%$ & $22=6 \%$ \\
\hline Based at Centre Non-West heritage & $20=5 \%$ & $2=1 \%$ & $22=6 \%$ \\
\hline Total & $294=76 \%$ & $93=24 \%$ & 387 \\
\hline \multicolumn{3}{|c|}{ Western heritage } & $326=84 \%$ \\
\hline \multicolumn{3}{|c|}{$\begin{array}{c}\text { Non-Western and } \\
\text { Centre non-Western heritage }\end{array}$} & $61=16 \%$ \\
\hline
\end{tabular}

Table A5. Security studies.

\begin{tabular}{cccc}
\hline & Male & Female & Total Publications \\
\hline Western heritage & $118=63 \%$ & $44=23 \%$ & $162=86 \%$ \\
\hline Based at Western University & $118=63 \%$ & $44=23 \%$ & $162=86 \%$ \\
\hline Based at non-Western University & $0=0 \%$ & $0=0 \%$ & $0=0 \%$ \\
\hline Non-Western heritage & $15=8 \%$ & $5=3 \%$ & $20=11 \%$ \\
\hline Based at Western University & $10=5 \%$ & $5=3 \%$ & $15=8 \%$ \\
\hline Based at non-Western University & $5=3 \%$ & $0=0 \%$ & $5=3 \%$ \\
\hline Centre Non-West heritage & $6=3 \%$ & $0=0 \%$ & $6=3 \%$ \\
\hline Based at Centre Non-West heritage & $\mathbf{4 9}$ & $\mathbf{1 8 8}$ \\
\hline Total Won-Western and \\
Centre non-Western heritage
\end{tabular}


Table A6. Studies in conflict and terrorism.

\begin{tabular}{cccc}
\hline & Male & Female & Total Publications \\
\hline Western heritage & $226=53 \%$ & $121=27 \%$ & $347=82 \%$ \\
\hline Based at Western University & $225=53 \%$ & $120=27 \%$ & $345=82$ \\
\hline Based at non-Western University & $1=1 \%$ & $1=1 \%$ & $2=1 \%$ \\
\hline Non-Western heritage & $33=8 \%$ & $7=2 \%$ & $40=9 \%$ \\
\hline Based at Western University & $17=4 \%$ & $7=2 \%$ & $24=6 \%$ \\
\hline Based at non-Western University & $16=4 \%$ & $0=0 \%$ & $16=4 \%$ \\
\hline Centre Non-West heritage & $21=5 \%$ & $15=4 \%$ & \\
\hline \\
Total \\
Centre non-Western heritage
\end{tabular}

Table A7. Media, war, and conflicts.

\begin{tabular}{cccc}
\hline & Male & Female & Total Publications \\
\hline Western heritage & $110=48 \%$ & $76=33 \%$ & $186=82 \%$ \\
\hline Based at Western University & $110=48 \%$ & $76=33 \%$ & $186=81 \%$ \\
\hline Based at non-Western University & $0=0 \%$ & $0=0 \%$ & $0=0 \%$ \\
\hline Non-Western heritage & $8=3 \%$ & $4=2 \%$ & $12=5 \%$ \\
\hline Based at Western University & $3=1 \%$ & $4=2 \%$ & $7=3 \%$ \\
\hline Based at non-Western University & $5=2 \%$ & $0=0 \%$ & $30=13 \%$ \\
\hline Centre Non-West heritage & $19=8 \%$ & $11=5 \%$ & $\mathbf{2 2 8}$ \\
\hline Total & $\mathbf{1 3 7}=\mathbf{6 0} \%$ & $\mathbf{9 1}=\mathbf{4 0} \%$ & $\mathbf{1 8 6}=\mathbf{8 2} \%$ \\
\hline Non-Western and & $\mathbf{3 2}=\mathbf{1 8 \%}$ \\
\hline
\end{tabular}

\section{References}

1. Stampnitzky, L. Disciplining Terror, How Scholars Invented Terrorism; Cambridge University Press: Cambridge, UK, 2014.

2. Herman, E.; O'Sullivan, G. The Terrorism Industry: The Scholars and Institutions that Shape Our View of Terror; Pantheon Books: New York, NY, USA, 1989.

3. Tinnes, J. A Resources List for Terrorism Research: Journals, Websites, Bibliographies. Perspect. Terror. 2018, 12, 115-142.

4. Freedman, B. Terrorism Research Centres: 100 Institutes, Programs and Organisations in the Field of Terrorism, Counter-Terrorism, Radicalisation and Asymmetric Warfare Studies. Perspect. Terror. 2010, 4, 5.

5. Van Dongen, T. 130+ (Counter-) Terrorism Research Centres-An Inventory. Perspect. Terror. 2018, 12, 86-124.

6. Schmid, A.; Jongman, A. Political Terrorism: A New Guide to Actors, Authors, Concepts, Data Bases, Theories, and Literature; Routledge: Abingdon, UK, 1988

7. Silke, A. Research on Terrorism: Trends, Achievements and Failures; Frank Cass: London, UK, 2004.

8. Ranstorp, M. Mapping Terrorism Research State of the Art, Gaps and Future Direction; Routledge: London, UK, 2007.

9. Jackson, R. The Study of Terrorism 10 Years After 9/11: Successes, Issues, Challenges. Uluslararası Iliş̧kiler 2012, 8, 1-16. 
10. Sageman, M. The Stagnation in Terrorism Research. Terror. Political Violence 2014, 26, 565-580. [CrossRef]

11. Gearon, L. Terrorism and counterterrorism policy and research in UK universities (1997-2017): An analytic-structural review of the literature and related sources. Policy Rev. High. Educ. 2018, 2, 32-60. [CrossRef]

12. Jackson, R.; Smyth, M.; Gunning, J. Critical Terrorism Studies: A New Research Agenda; Routledge: London, UK, 2009.

13. Kundani, A. The Muslims Are Coming; Verso: London, UK, 2014.

14. Jackson, R. Constructing Enemies: "Islamic Terrorism" in Political and Academic Discourse. Gov. Oppos. 2007, 42, 394-426. [CrossRef]

15. McCauley, C.; Moskalenko, S. Some Things We Think We've Learned Since 9/11: A Commentary on Marc Sageman's “The Stagnation in Terrorism Research". Terror. Political Violence 2014, 26, 601-606. [CrossRef]

16. Stern, J. Response to Marc Sageman's “The Stagnation in Terrorism Research". Terror. Political Violence 2014, 26, 607-613. [CrossRef]

17. Schmid, A. Comments on Marc Sageman's Polemic “The Stagnation in Terrorism Research". Terror. Political Violence 2014, 26, 587-595. [CrossRef]

18. Mignolo, W. The Darker Side of Western Modernity: Global Futures, Decolonial Options; Duke University Press: Durham, NC, USA, 2011.

19. Quijano, A. Coloniality and Modernity/Rationality. Cult. Stud. 2007, 21, 168-178. [CrossRef]

20. Joseph-Salisbury, R. Whiteness Characterises Higher Education Institutions-So Why are We Surprised by Racism? The Conversation, 10 March 2018. Available online: https:/ / theconversation.com/whiteness-characterises-higher-education-institutions-sowhy-are-we-surprised-by-racism-93147(accessed on 18 November 2020).

21. Bhambra, G.; Nisancioglu, K.; Cebrial, D. Decolonising the University; Pluto Press: London, UK, 2018.

22. Andrews, K. The challenge for black studies in the neoliberal university. In Decolonising the University; Bhambra, G.K., Gebrial, D., Nişanciolu, K., Eds.; Pluto Press: London, UK, 2018.

23. Arday, J. Dismantling power and privilege through reflexivity: Negotiating normative Whiteness, the Eurocentric curriculum and racial micro- aggressions within the Academy. Whiteness Educ. 2018, 3, 141-161. [CrossRef]

24. Alejandro, A. Western Dominance in International Relations? The Internationalisation of IR in Brazil and India; Routledge: London, UK, 2018.

25. Deckert, A. Neo-Colonial Criminology: Quantifying Silence. Afr. J. Criminol. Justice Stud. 2014, 8, 39-63.

26. Tuck, E.; Yang, K. Decolonization is not a metaphor. Decoloniz. Indig. Educ. Soc. 2012, 1, 1-40.

27. Lewis, S. Releasing a tradition. Camb. J. Anthr. 2018, 36, 21-33. [CrossRef]

28. Mogstad, H.; Tse, S. Decolonising anthropology. Camb. J. Anthr. 2018, 36, 53-72. [CrossRef]

29. Maldonado-Torres, N. Thinking through the decolonial turn: Post-continental Interventions in theory, philosophy, and critiqueAn introduction. Transmodernity J. Peripher. Cult. Prod. Luso-Hisp. World 2011, 1, 1-15.

30. Behari-Leak, K. Decolonial turns, postcolonial shifts, and cultural connections: Are we there yet? Engl. Acad. Rev. 2019, 36, 58-68. [CrossRef]

31. Thiong'o, N.W. Decolonising the Mind: The Politics of Language in African Literature; Zimbabwe Publishing House: Harare, Zimbabwe, 1986.

32. Grosfoguel, R. Decolonising Post-Colonial Studies and Paradigms of Political-Economy: Transmodernity, Decolonial Thinking, and Global Coloniality. Transmodernity J. Peripher. Cult. Prod. Luso-Hisp. World 2011, 1. Available online: https://escholarship. $\mathrm{org} / \mathrm{uc} /$ item/21k6t3fq (accessed on 17 November 2020).

33. Grosfoguel, R. The Structure of Knowledge in Westernized Universities: Epistemic Racism/Sexism and the Four Genocides/Epistemicides of the Long 16th Century. Hum. Arch. J. Sociol. Self Knowl. 2013, 11, 9-22.

34. Sedgewick, M. The Concept of Radicalisation as a Source of Confusion. Terror. Political Violence 2010, 22, 479-494. [CrossRef]

35. Groothuis, S. Researching race, racialisation, and racism in critical terrorism studies: Clarifying conceptual ambiguities. Crit. Stud. Terror. 2020, 13, 680-701. [CrossRef]

36. Sian, K. Navigating Institutional Racism in British Universities; Palgrave MacMillan: London, UK, 2019.

37. Walter, A.; Epps, E.; Guillory, E.; Susan, S.; Bonous-Hammarth, M. The Black Academic: Faculty Status Among African Americans in US Higher Education. J. Negro Educ. 2000, 69, 112-127.

38. Brunsma, D.; Embrick, D.; Shin, J. Graduate Students of Color: Race, Racism, and Mentoring in the White Waters of Academia. Sociol. Race Ethn. 2017, 3, 1-13. [CrossRef]

39. Arday, J.; Mirza, S. Dismantling Race in Higher Education: Racism, Whiteness and Decolonising the Academy; Palgrave Macmillan: London, UK, 2019.

40. Platter, S.; Mooney-Somers, J.; Barclay, L.; Boulton, J. Hitting the white ceiling: Structural racism and Aboriginal and Torres Strait Islander university graduates. J. Sociol. 2020, 56, 487-504. [CrossRef]

41. Ahmadi, S.; Cole, D. Islamophobia in Higher Education: Combating Discrimination and Creating Understanding; Stylus Publishing: Sterling, VA, USA, 2020.

42. Alatas, S.H. Intellectual Imperialism: Definition, Traits, and Problems. Southeast J. Soc. Sci. 2000, 28, $23-45$.

43. Alatas, S.F. Academic Dependency and the Global Division of Labour in the Social Sciences. Curr. Sociol. 2003, 51, 599-613. [CrossRef]

44. Agozino, B. Counter-Colonial Criminology, A Critique of Imperialist Reason; Pluto Press: London, UK, 2003. 
45. Cunneen, C.; Tauri, J. Indigenous Criminology; Policy Press: Bristol, UK, 2016.

46. Liu, J.; Hebenton, B.; Jou, S. Handbook to Asian Criminology; Springer: Berlin, Germany, 2013.

47. Agozino, B. Imperialism, crime and criminology: Towards the decolonisation of criminology. Crime Law Soc. Chang. 2004, 41, 343-358. [CrossRef]

48. Bowling, B. Transnational criminology and the globalisation of harm production. In What is Criminology? Bosworth, M., Hoyle, C., Eds.; Oxford University Press: Oxford, UK, 2011.

49. Carrington, K.; Hogg, R.; Sozzo, M. Southern Criminology. Br. J. Criminol. 2019, 56, 1-20. [CrossRef]

50. Connell, R. Southern Theory; Polity Press: London, UK, 2007.

51. Moosavi, L. A friendly critique of 'Asian criminology' and 'Southern criminology'. Br. J. Criminol. 2019, 59, 257-275. [CrossRef]

52. Nye, M. Decolonising the Study of Religion. Open Libr. Hum. 2019, 5, 1-45.

53. Grosfoguel, R.; Hernandez, R.; Velasquez, E. Decolonising the Westernized University Interventions in Philosophy of Education from Within and Without; Rowman \& Littlefield: Lanham, MD, USA, 2016.

54. Bird, K.; Pitman, L. How diverse is your reading list? Exploring issues of representation and decolonisation in the UK. High. Educ. 2019, 79, 903-920. [CrossRef]

55. Morreira, S.; Luckett, K.; Kumalo, S.; Ramgotra, M. Confronting the complexities of decolonising curricula and pedagogy in higher education. Third World Themat. A Twq J. 2020, 5, 1-18. [CrossRef]

56. Alatas, F. Silencing as Method: Leaving Malay Studies out; National University of Singapore: Singapore, 2019; Available online: http:/ / www.fas.nus.edu.sg/malay/documents / Alatas.SilencingasMethod.pdf (accessed on 12 September 2020).

57. Collyer, F. Global patterns in the publishing of academic knowledge: Global North, global South. Curr. Sociol. 2018, 66, 56-73. [CrossRef]

58. Braine, G. The Challenge of Academic Publishing: A Hong Kong Perspective. Tesol Q. 2005, 39, 707-716. [CrossRef]

59. Galliers, R.; Meadows, M. A Discipline Divided: Globalisation and Parochialism in Information Systems Research. Commun. Assoc. Inf. Syst. 2003, 11, 108-117. [CrossRef]

60. Ozbilgin, M. International" human resource management Academic parochialism in editorial boards of the "top" 22 journals on international human resource management. Pers. Rev. 2004, 33, 205-221. [CrossRef]

61. Noonan, J.; Bristol, T. "Taking Care of Your Own": Parochialism, Pride of Place, and the Drive to Diversify Teaching. AERA Open. 2020, 6, 1-12. [CrossRef]

62. Lundine, J.; Bourgeaultb, I.; Glontic, K.; Hutchinsone, E.; Balabanovae, D. “I don't see gender": Conceptualising a gendered system of academic publishing. Soc. Sci. Med. 2019, 235, 112388. [CrossRef]

63. Basford, T.; Offermann, L.; Behrend, T. Do You See What I See? Perceptions of Gender Microaggressions in the Workplace. Psychol. Women Q. 2014, 38, 340-349. [CrossRef]

64. Anderson, T. Black Encounter of Racism and Elitism in White Academe: A Critique of the System. J. Black Stud. 1988, 18, 259-272. [CrossRef]

65. Dowson, J.; Coggins, N.; Dolechekc, M.; Gisela Fosadoa, G. Toolkits for Equity: An Antiracist Framework for Scholarly Publishing. Ser. Rev. 2020, 46, 170-174. [CrossRef]

66. Politzer-Ahles, S.; Girolamo, T.; Ghali, S. Preliminary evidence of linguistic bias in academic reviewing. J. Engl. Acad. Purp. 2020, 47.

67. Crilly, J. Decolonising the library: A theoretical exploration. J. Focus 2019, 4, 1. Available online: https://sparkjournal.arts.ac.uk/ index.php/spark/article/view/123/190 (accessed on 19 September 2020).

68. Chen, H.; Reid, E.; Siani, S.; Silke, A.; Ganor, B. Terrorism Informatics: Knowledge Management and Data Mining for Homeland Security; Springer: Berlin, Germany, 2008.

69. Silke, A.; Schmidt-Peterson, J. The Golden Age? What the 100 Most Cited Articles in Terrorism Studies Tell Us. J. Terror. Political Violence 2017, 29, 692-712. [CrossRef]

70. Schuurman, B. Research on Terrorism, 2007-2016: A Review of Data, Methods, and Authorship. Terror. Political Violence 2018. Available online: https:/ / www.tandfonline.com/doi/pdf/10.1080/09546553.2018.1439023?needAccess=true (accessed on 15 September 2020). [CrossRef]

71. Scrivens, R. Academic Theses (Ph.D. and MA) on Terrorism and Counter- Terrorism-Related Issues, written in English between 2013 and 2017. Perspect. Terror. 2017, 11, 140-151.

72. Grosfoguel, R. From Postcolonial Studies to Decolonial Studies: Decolonising Postcolonial Studies. Rev. J. Fernand Braudel Cent. 2006, 29, 143-166.

73. Mignolo, W. Globalisation and the Geopolitics of Knowledge: The Role of the Humanities in the Corporate University. Nepantla Views South 2003, 4, 97-119. 